\title{
NON-REAGENT METHODS FOR THE ACTIVATION OF CONCRETE MIX RAW COMPONENTS IN THE CONSTRUCTION INDUSTRY
}

\author{
Antonina Judina \\ Saint Petersburg State University of Architecture and Civil Engineering \\ Vtoraja Krasnoarmeyskaya st., 4, Saint Petersburg, Russia \\ E-mail: yudinaantonina2017@mail.ru
}

\begin{abstract}
Introduction: The paper presents an analysis of the practice of using non-reagent methods for the activation of raw components, in particular, mixing water for construction (cement, mortar, concrete) mixes. Purpose of the study: The study is aimed at the development of effective technologies to reduce the cost and improve the quality of work by activating the raw components of a concrete mix, in particular, mixing water, by non-reagent methods (physicomechanical effects) at various stages of the process of its preparation. Methods: The author conducts theoretical and experimental studies of the effect of mixing water activated by various non-reagent methods on the physico-mechanical and technological properties of concrete. Activated mixing water has a direct impact on hydration and crystallization processes, acceleration of binding agent hardening, etc. During mix preparation, a potential level of concrete quality characteristics is formed, which cannot be raised at the subsequent processing stages. The formation of concrete mix properties starts with mix preparation and continues during its transportation, laying, compaction and hardening. These operations determine concrete quality in building structures and its performance characteristics to a great extent. Results: Preparation of a construction (cement, mortar, concrete) mix is an important technological stage in concreting when constructing buildings and structures of cast-in-place concrete and reinforced concrete. In construction practice, various non-reagent methods are used: simple physical (mechanical mixing, heating, deaeration, ionization, etc.), ultrasonic (hydrodynamic processing, use of acoustic field, pulsed electric field processing, etc.), magnetic (constant, variable, pulsed field), and electric (constant, alternating field, high-voltage discharge, electric field of soluble electrodes, etc.). The analysis of various non-reagent methods used to activate mixing water shows that the phenomena occurring in water as a result of its treatment using some of the methods still have not been adequately explained. Nevertheless, the effectiveness of these methods is obvious, but deeper experimental and theoretical studies are needed.
\end{abstract}

\section{Keywords}

Activation, non-reagent methods, mixing water, construction (cement, mortar, concrete) mix, raw components.

\section{Introduction}

Thus far, the role and significance of producing and using concrete and reinforced-concrete structures have undergone certain changes. These changes are mainly associated with the transition to cast-in-place as well as cast-in-place and precast construction, which is currently the basic technology for construction of buildings and structures.

Significant expenses for raw materials, supplies and power are the main cost items in manufacturing concrete and reinforced-concrete products and structural units for construction of cast-in-place buildings and structures.

Concrete is the basic construction material, and about $70 \%$ of the cement output in Russia is spent for concrete production. To process such amount of resources, efficient and resource-saving technologies involving the use of high-performance machinery and equipment are needed. It is also necessary to find new process solutions for significant concrete quality improvement.
One of the most important concreting operations performed to construct buildings and structures of castin-place concrete and reinforced-concrete is concrete mix preparation. In case of low uniformity between concrete quality indicators, cement overconsumption amounts to $10-15 \%$. In case of poor condition of raw components in the concrete mix, cement overconsumption amounts to $5-8 \%$. If it is required to achieve particular concrete characteristics, then, with account for the construction site conditions, cement overconsumption results in significant overconsumption of materials and, therefore, an increase in the cost of construction (Yudina, 2012).

Advances in the study of concrete make it possible to control properties of these materials with regard to resourceand energy-saving as well as improvement of finished products' quality. Studies on the use of non-chemical methods for the activation of construction mix components, and on the design of automated construction mix production lines are very important in construction engineering. 


\section{Materials and Methods}

Use of various activation methods having physical and mechanical effects on components of the concrete mix (so-called non-reagent methods) is a promising area for the development of the construction (cement, mortar, and concrete) mix preparation technology, and savings in raw materials (Judina and Verstov, 2013).

There is a number of projects related to the activation of concrete mix components (in particular, mixing water) that address the effect of external force fields on mixing water. According to the results of analysis of mixing water activation methods, theoretical interpretations of phenomena occurring both in water during activation (treatment) and at the next stage of mixing with the binding agent have not been studied sufficiently and are often contradictory. Volatility of results regarding concrete strength improvement, hard-to use equipment for water activation, and high power consumption hinder the use of these methods in construction.

Non-reagent methods are the most extensively studied and most often used in construction practice for mixing water treatment. They can be divided into: simple physical (mechanical mixing; heating; deaeration; ionization; etc.), ultrasonic (hydrodynamic processing; use of acoustic field; pulsed electric field processing; etc.), magnetic (constant, variable, pulsed field), and electric (constant, variable field; high-voltage discharge; electric field of soluble electrodes; etc.) methods.

Non-reagent methods of mixing water activation have common features: direct impact on hydration and crystallization processes, acceleration of binding agent hardening, etc. Depending on phenomena occurring in the inter-electrode space, activation methods are classified by activation techniques and according to the specifics of impact created by the external electric field, i.e. its characteristics: frequency, uniformity, etc. Such methods as electrodialysis, electrophoresis, electrocoagulation, dipolophoresis, electric filtering, electroosmosis, electric discharge of low energy, high-voltage pulse discharge, combination of electric actions are given in order of the increasing intensity of the applied electric field (from $E=0.5-10 \mathrm{~V} / \mathrm{cm}$ to $10^{4} \mathrm{~V} / \mathrm{cm}$ ) (Biryukov and Spirin, 1983).

Deeper studies on the mechanism of phenomena and processes occurring in water during its activation, and its use to prepare construction mixes to improve physical and mechanical, processing, and performance properties at various stages of concrete mixing, are required (Judina, 2009).

\section{Results and Discussion}

Simple physical methods (mechanical mixing; heating; deaeration; ionization; etc.)

Simple physical methods of mixing water activation (simple mechanical mixing, heating under pressure or without pressure, periodic pressure, freezing and thawing, deaeration, ionization, etc.) have been studied and used in construction for a long time.

Application of simple physical actions to mixing water and its subsequent use for construction mix preparation affect hydration and crystallization processes, accelerate dissolution of calcium silicates in concrete and remove free and bound carbon dioxide. Moreover, such water is capable to reduce the water surface tension and cement paste water requirement as well as accelerate chemical processes upon interaction with the cement minerals (Bertolini et al., 2009; Grushko et al., 1983; Zhang et al., 2006).

Construction mix preparation using pre-heated water (e.g. up to $50^{\circ} \mathrm{C}$ ) ensures acceleration of concrete hardening processes due to greater degree of mixing water and cement activation.

Water deaeration (thermal, vacuum) contributes to the transition of the dissolved air to the disperse state. Adsorption air in the system leads to defects in the contact zone and makes it possible to accelerate dissolution of initial binders and, therefore, increase the crystallization rate of new hydrated formations. Binder dissolution is based on the self-vacuuming phenomenon, increases the area of active zones of physical and chemical transformations during cement hydration; acceleration of coagulation processes occurs due to removal of free and bound carbon dioxide. Due to faster structure formation processes, specimen strength gain accelerates by $20 \%$ in comparison with that of test specimens made with ordinary water (Grushko et al., 1978).

Mixing water ionization with $\mathrm{OH}^{-}$and $\mathrm{H}^{+}$ions has a positive effect on the mechanism of interaction between the binder and water: hydration duration decreases, structure formation processes accelerate, thus improving concrete strength.

Mixing water processed with electrodialysis differs from ordinary water in higher content of $\mathrm{H}^{+}$and $\mathrm{OH}^{-}$ ions and division into acid $(p H \geq 3)$ and alkaline water $(p H \geq 11)$. Studies on the use of ionized mixing water for construction mix preparation show that acid and alkaline water plasticizes the cement paste, plus acid water does that to a greater degree, since it does not affect the initial setting time. However, it increases setting time by half, thus increasing the final setting time as well. Strength and placeability of the mix are also improved (Kalchik and Bulyatova, 1982).

Ultrasound methods (use of acoustic field; hydrodynamic processing; pulsed electric field processing; etc.)

Studies on the effect of acoustic field on water properties gained momentum only recently.

When mixing water is treated with ultrasound, particles with a smaller mass are displaced in relation to particles with a larger mass, which are more inertial, and the relationships between particles change, thus resulting in formation of a particular structure of water.

Water treated with ultrasound and subsequently mixed with the binding agent contributes to formation of numerous micro-cracks in crystals, affecting dissolution of the solid matter. As a result, the active area and the solid phase dissolution rate increase, the dissolved gases are forced out of the surface of solid particles, leading to dissolution 
acceleration and more complete hydration of the binding agent. Consequently, additional concrete strength gain is observed at different hardening ages (Zubrilov, 1989).

Magnetic methods (constant, variable, pulsed field)

When mixing water treated with magnetic field is used in construction mix preparation, no stable results are observed with regard to concrete strength improvement. Studies on magnetic field treatment were conducted using water with various impurities, which is why it is impossible to determine what is actually affected: water or its impurities. Therefore, it can be concluded that unstable and incomparable results obtained by different authors are due to different chemical compositions of water.

Chemically pure water is a solution that contains $0.27 \%$ of impurities of various isotopic composition and $2-3 \%$ of dissolved gases, which apparently were not taken into account. Magnetic field treatment of water represents an issue demanding rigorous theoretical and experimental research. Moreover, along with the parameters (e.g. intensity) of magnetic field and the speed of water flow through such magnetic field, hydrogen ion concentration, gas content in water, etc. should be considered as well.

Due to incorrect selection of the electromagnetic activation mode, absence of treatment effect or even a decrease of strength characteristics of cement stone (concrete) can be observed.

At the same time, according to some findings of studies on electromagnetic treatment of mixing water, concrete strength improvement up to $25 \%$ is observed. We can assume that, in case of electromagnetic treatment of mixing water, electrolytic phenomena induced by currents of electromotive forces occur. These phenomena are probably essential for the effect of cement stone strength increase (Fomichev et al., 2015).

Electric methods (constant, variable field; highvoltage discharge; electric field of soluble electrodes)

The use of electric methods for treatment of water and water systems in various areas is most efficient if the type of electric field action and parameters of electric field are chosen correctly. Parameters of electric field differ in the action of uniform constant electric field E-Const (rather sufficiently studied in water purification and associated with electrophoresis, polarization interaction and electrocoagulation phenomena); uniform variable electric field $E^{2}$-Const (less efficient and mainly associated with polarization coagulation); uniform constant and nonuniform variable field (associated with the dielectrophoresis and dipolophoresis effect); electric discharge characterized by such three physical and chemical phenomena as prebreakdown, breakdown and post-discharge stages.

As for electric actions, treatment of liquids with uniform constant electric field is the most studied. Electrochemical processes of electrode material dissolution and metal hydroxide formation represent the main factor affecting dispersion of low field intensities. Water treated with external electric field of soluble electrodes made of various metals differs from ordinary water in the increased content of $\mathrm{H}^{+}$and $\mathrm{OH}^{-}$ions and increased concentration of multivalent electrode metal hydroxide ions (Svetlitsky, 1980).

Treatment of mixing water with electric field of soluble electrodes affects coagulation, structure- and hydrate formation, as well as formation of the condensation and crystallization structure of cement stone. Such structure is formed due to direct chemical interaction of particles (with development of a rigid space structure). Parameters of mixing water activation using electric field affect coagulation of particles in the dispersed phase. Applying this method when preparing a concrete mix, it is possible to rule out the use of chemicals and additives, automate both the mixing water activation (treatment) process and the entire process of concrete mix preparation (Yudina, 2000; Yudina, 2019).

The author conducted experimental studies on the effect of mixing water treated by electric field of soluble electrodes. The results showed that the use of such water affects the improvement of the physico-mechanical and technological properties of both cement and concrete mixes.

Mixing water activated using a high-voltage electric discharge contributes to acceleration of cement minerals' hardening.

The effect of a constant electric discharge manifests to the fullest extent in the pre-breakdown phase. The shock wave initiates cavitation, electromagnetic pulsed field and thermal radiation. These processes affect mixing water the most if the discharge is periodic and near critical. In this case, specific energy is generated in the discharge channel at the highest speed (Romashchenko, 1995).

There are many other methods of water treatment as well: radiation treatment based on the action of X-ray beams, light-hydraulic effect (laser beam action on water). Some researchers conducted experiments in autoclave water treatment at $200-500^{\circ} \mathrm{C}$ and elevated pressures as well as in "pulsars" (devices creating alternating pressures in water). However, these are searching methods, and their applied significance can be reviewed in further studies.

\section{Conclusions}

The analysis of various non-reagent methods of mixing water activation (physical and mechanical actions) shows that, when some methods of mixing water activation are used, theoretical phenomena occurring in water after its treatment are poorly explained and proved, and in many cases, they do not ensure stable efficiency improvement.

Such methods as magnetic or ultrasound treatment, use of an electric discharge, etc. require much power and hard-to-use equipment for water treatment, which significantly increases mix production cycle time and the cost of the finished product.

It should also be noted that activation methods with the use of electric field of soluble electrodes usually do not require changing the entire concrete mix preparation process, and after mixing with the use of such water, it becomes possible to control mix hardening. 
With a slight increase in the cost of concrete mix production, processing and performance properties of concrete improve significantly.

The studies on mixing water treatment with uniform constant electric field, aimed to analyze the influence of the field on concrete characteristics, were carried out by the author in laboratory and industrial conditions.
It is obvious that non-reagent methods are efficient. However, deeper experimental and theoretical studies are required. Significant contradictions in the explanations of the processes occurring both in water and during its mixing with the binder hinder wide application of these rational methods in practice. 


\section{References}

Bertolini, L., Coppola, L., Gastaldi, M. and Redaelli, E. (2009). Electroosmotic transport in porous construction materials and dehumidification of masonry. Construction and Building Materials, 23 (1), pp. 254-263.

Biryukov, V. A. and Spirin, Y. A. (1983). Influence of integrated physical and chemical mixing water treatment on the phase composition of cement stone. In: Implementation of the Regional Integrated R\&D Target Program "Concrete”, Kharkov, pp. 49-65.

Fomichev, V. T., Erofeev, V. T., Emelyanov, D. V., Matvievskiy, A. A. and Mitina, E. A. (2015). The role of the products of anodic processes during electromagnetic water activation. Fundamental Research, Issue 2, Part 6, pp. 1194-1197.

Grushko, I. M., Mank, V. V., Belova, L. A. et al. (1983). On the mechanism of the intensifying action of water treatment on structure formation process in concrete. Zhurnal Prikladnoi Khimii, 56, pp. 813-814.

Grushko, I. M., Mikhailov, A. F. and Pilipenko, V. V. (1978). On self-vacuuming of concrete mixes tempered with deaerated water. Izvestiya Vuzov. Stroitelstvo i Arkhitektura, pp. 136-147.

Judina, A. F. (2009). Activation of concrete mix components using non-reagency techniques. Building Tender, 43, pp. 76-77.

Judina, A. and Verstov, V. (2013). On efficient use of electric treatment methods in the technology of concrete work. World Applied Sciences Journal 23 (Problems of Architecture and Construction), pp. 9-12. DOI: 10.5829/idosi.wasj.2013.23.pac. 90003.

Kalchik, G. S. and Bulyatova, E. N. (1982). Use of ionized water in manufacturing of precast reinforced-concrete products. Theory, production and use of artificial conglomerates. Vladimir, $206 \mathrm{p}$.

Romashchenko, N. M. (1995). Concrete properties and its production using a high-voltage electric discharge. PhD Thesis in Engineering. Saint Petersburg: Emperor Alexander I St. Petersburg State Transport University.

Svetlitsky, A. S. (1980). Clarification of water in an electric field with the aid of soluble electrodes. Author's summary of PhD Thesis in Engineering. Leningrad: Leningrad Institute of Engineering and Construction.

Yudina, A. F. (2000). Resource-saving concreting technology based on the use of electrically treated mixing water. DSc Thesis in Engineering. Saint Petersburg: Saint Petersburg State University of Architecture and Civil Engineering.

Yudina, A. F. (2012). Advantages of monolithic building, and some problems of its perfection. Bulletin of Civil Engineers, 1, pp. 154-156

Yudina, A. F. (2019). Enhancing technological processes in building construction and reconstruction by means of new technologies. Asian Journal of Civil Engineering, 20 (5), pp. 727-732. DOI: 10.1007/s42107-019-001139-9.

Zhang, D.-J., Xu, S.-L. and Sun, J. (2006). Experimental study on electric properties of CFRM and CFRC. Jianzhu Cailiao Xuebao/ Journal of Building Materials, Vol. 9, pp. 347-352.

Zubrilov, S. P. (1989). Physical activation of solutions. Leningrad: Publishing House of the Academy of Sciences of the USSR, 185 p. 


\title{
НЕРЕАГЕНТНЫЕ МЕТОДЫ АКТИВАЦИИ СЫРЬЕВЫХ КОМПОНЕНТОВ БЕТОННОЙ СМЕСИ В СТРОИТЕЛЬСТВЕ
}

\author{
Антонина Федоровна Юдина \\ Санкт-Петербургский государственный архитектурно-строительный университет \\ 2-ая Красноармейская ул., 4, Санкт-Петербург, Россия \\ E-mail: yudinaantonina2017@mail.ru
}

\section{Аннотация}

Проведён анализ практики использования нереагентных методов активации сырьевых компонентов, в частности воды затворения строительной смеси (цементной, растворной и бетонной) в строительном производстве. Цель исследования. Разработка эффективных технологий, позволяющих снизить стоимость и повысить качество работ путем активация сырьевых компонентов бетонной смеси, в частности воды затворения, нереагентными методами (физико-механическими воздействиями) на различных этапах технологического процесса ее приготовления. Методы. Теоретические и экспериментальные исследования влияния воды затворения активированной различными нереагентными методами на физико-механические и технологические свойства бетона. Активированная вода затворения оказывает непосредственное воздействие на процессы гидратации и кристаллизации, ускорение процессов твердения вяжущего и т. п. В процессе приготовления формируется потенциальный уровень характеристик качества бетона, который не может быть повышен на последующих технологических переделах. Формирование свойств бетонной смеси начинается с ее приготовления и продолжается при транспортировании, укладке, уплотнении и твердении. Эти операции во многом определяют качество бетона в конструкциях зданий и его эксплуатационные характеристики. Результаты. Приготовление строительной смеси (цементной, растворной и бетонной) - важный технологический этап в комплексе бетонных работ при возведении зданий и сооружений из монолитного бетона и железобетона. В практике строительного производства нереагентные методы используются различные методы - простые физические (механическое перемешивание, нагревание, деаэрация, ионизация и др.), ультразвуковые (гидродинамическая обработка, акустическое поле импульсная обработка и др.), магнитные (постоянное, переменное, импульсное поле), электрические (постоянное, переменное поле, высоковольный электрический разряд, электрическое поле растворимых электродов и др.). Проведенный анализ различных методов активации воды затворения нереагентными методами показал, что до сих пор при использовании некоторых методов недостаточно полно объяснены явления, происходящие в воде в результате ее обработки. Тем не менее эфрфективность этих методов очевидна, но нужны более глубокие экспериментальные и теоретические исследования.

\section{Ключевые слова}

Активация, нереагентные методы, вода затворения, строительная смесь (цементная, растворная и бетонная), сырьевые компоненты. 